\title{
Hygienic Setting of Catering Establishments in AgaroTown, Southwestern Ethiopia
}

\author{
Biruk Gobena ${ }^{1 *}$ and Wondwossen Birke ${ }^{2}$ \\ 1Ethiopian Environment and Forest Research Institute, Environmental Pollution Management Research Directorate, Ethiopia \\ 2Jimma University, Environmental Health Sciences and Technology Department, Ethiopia
}

Submission:March 30, 2018; Published: April 23, 2018

*Corresponding author: Biruk Gobena, Ethiopian Environment and Forest Research Institute, Environmental Pollution Management Research, Ethopian, Email: birukgobena@gmail.com

\begin{abstract}
Food contaminated by disease causing organisms, and chemicals are considered as a major public health concern all over the world. If good sanitation is not practiced in catering establishments, a chance of food contamination and food borne illness are extremely high. Hence, a cross-sectional study was conducted to assess the hygienic settings of catering establishments of Agaro town. Data was collected by using pre-tested, structured questionnaires and observational check list. The finding of the study was analyzed using Microsoft Excel version 10 and Minitab version 16.Among 102 foods catering establishments evaluated, $97.1 \%$ of them have access to latrine in which traditional pit latrine is the dominant. Eighty three percent of the catering establishments were disposing their liquid waste indiscriminately. Ninety two percent of the catering establishments have separate kitchen where vectors were observed in $92.5 \%$ of them. Three Compartment dish washing practice was found only in $44.1 \%$ of the establishments. Sixty two percent of catering establishments were inspected during the last six months; whereas $2.9 \%$ of them were not ever inspected until the day of this survey. Accordingly, merely $5.9 \%$ of food handlers had medical checkup during the last six month. There is statistical evidence $(\mathrm{p}<0.05)$ that the availability of latrine and hand washing facility is associated with pattern of inspection. Generally there was poor hygienic setting in majority of catering establishments. To improve the hygienic setting of catering establishments the enforcement of sanitary provisions and training on hygienic catering service is required.
\end{abstract}

Keywords: Catering establishment; Food hygiene; Food handler; Waste management

\section{Introduction}

Food is one of the indispensable requirements of human being worldwide. The supply of adequate and wholesome food is one of the essential part of primary health care and food contaminated by disease causing organisms are considered as a major public health problem all over the world [1]. The fact that the regular monitoring and surveillance by local health authorities and the municipality is rare in our country, catering establishments provide food and drink services to a relatively large number of users in the form of breakfast, lunch, dinner or beverages. In many urban centers eating and drinking public establishments such as hotels, restaurant, snack bars is common in many countries. If sanitary and hygienic norms are not strictly followed these establishments may cause a possible risk of infection since they prepare, handle and serve large quantities of food and drinks to a large group of people within a short period of time [2]. Opportunities for food contamination and food borne illness are very high in urban centers because of the high density of population and scarcity of safe waste disposal. In contrast to rural area, a great majority of the population eats food from public food establishments or similar mass catering places. In many of these establishments hygienic food handling practice are poor [3]. Also, the health status and the level of personal hygiene of the food handlers in the eating establishments were found to be unsatisfactory [4]. Consequently, food service establishments can be sources of food borne illness and food handlers contribute to food borne illness out break [5]. In Ethiopia, although sanitary condition of catering establishments in Ambo, Addis Ababa, Bahirdar, Awassa, Zeway, Mekelle and Awash-Sebat Kilo town have been reported, still the studies are not at stage which can be used to generalize the hygienic setting of catering establishments in Ethiopia. On the basis of the above background, this study was interested at studying the hygienic setting of catering establishments in Agaro town, Jimma zone, Oromia region, Ethiopia. The result of this study can be used as baseline data for regulatory bodies to improve the sanitary setting of catering establishments.

\section{Materials and Methods}

A cross-sectional study was conducted to assess the hygienic setting of catering establishments of Agarotown in March, 2013. 
Agaro town is located in Jimma zone of the Oromia Region, south western Ethiopia at latitude and longitude of $7^{\circ} 51^{\prime} \mathrm{N} 36^{\circ} 35^{\prime} \mathrm{E}$, and an elevation of 1560 meters above sea level. The town has estimated total population of 25,458 of whom 12,946 are men and 12,512 are women [6]. The town has a total of 139 catering establishments. Both licensed and unlicensed catering was included in this study. The sample size 102 was computed using statistical formula for simple random sampling technique from the total $(n=139)$ of establishments [7]. The establishments were stratified by the type of service they provide into the following strata: hotel, bar, restaurant and snack bar. A proportional sample size was determined for each stratum using systematic random sampling with proportional allocation method. Only one food handler was interviewed from one establishment by random selection. Ethical approval and clearance was obtained from respective authorities. The objectives of this study were communicated to the owner of the establishments and verbal consents of owners and participants were obtained. Data collectors (Environmental Health Science graduate class students) have taken training on data collection tool. Data were collected using questioner and check list which were prepared in English language and translated in to local language during interview and retranslated back to English language under principal investigators supervision to increase data quality [810]. Data was compiled and analyzed using Microsoft excels version 10and presented using tables, pie charts and graphs. Chi-square test was performed using Minitab version 16to test for association between variables. P-value $<0.05$ was considered to indicate statistically significant association. Frequency distributions and percentages with 95\% confidence level (C.I) were calculated for statistical significance tests.

The following operational definitions were used in this study [11-14]

Adequate space: if there is free space for the movement of any person beside any other equipment.

Bad lighting: a room in which a health person cannot easily identify objects.

Bad ventilation: rooms which has a disagreeable odor and have no window.

Table 1: Pattern of inspection, license status and service year of catering establishments in Agaro town in March, 2013.

\begin{tabular}{|c|c|c|c|}
\hline \multirow{2}{*}{ Characteristics } & \multirow{2}{*}{ Time period } & \multicolumn{2}{|c|}{ Number of establishments } \\
\hline & & Frequency & $\%$ \\
\hline \multirow{3}{*}{ Service year } & $>25$ & 15 & 14.7 \\
\hline & $10-25$ & 41 & 40.2 \\
\hline & $<10$ & 46 & 45.1 \\
\hline \multirow{4}{*}{ Supervisory visit } & No recallable visit & 3 & 2.9 \\
\hline & 1 years ago & 13 & 12.7 \\
\hline & 6 months ago & 24 & 23.5 \\
\hline & $<6$ months ago & 62 & 60.8 \\
\hline
\end{tabular}

Catering establishment: establishments those engaged in the work of providing food and drinks for the consumers such as hotel, bar, restaurant and snack bar.

Easily Washable floor: a floor which is made of easily washable material i.e. concrete.

Easily washable wall: a wall which is made of easily washable material i.e. block/brick and iron products.

Fair lighting: a room in which a health person without major visual problem can identify objects.

Fair ventilation: a room relatively free from disagreeable

Good hygienic setting: if the water supplies system, solid waste disposal system, and liquid waste management system of the establishments was in a manner that avoids or reduce contamination food.

Good ventilation: a room free from a disagreeable odor and have greater than equal to two openable windows.

Poor hygienic setting: if the water supply system, solid waste disposal system, and liquid waste management system of the establishments was not in manner that avoid or reduce contamination food.

Good lighting: a room in which a healthy person without any visual problem can easily identify objects.

Proper storage: a storage which avoid accessibility of vectors and rodents to sanitized food utensils and ready to eat food.

\section{Results and Discussion}

\section{General Information}

From 102 catering establishments included in this study, $92.2 \%$ of them were licensed while $7.8 \%$ were not licensed (data not shown). About86 (84.4\%) were inspected in the last six months and $13(12.7 \%)$ were inspected one years ago. Whereas $3(2.9 \%)$ were not inspected until the day of this survey. Forty six $(45.1 \%)$ of catering establishment has service year of less than 10 year where as the rest $56(54.9 \%)$ has service year of greater than or equal to 10 year as shown in Table 1. odor and have at least one open able window. 


\section{License Status}

\begin{tabular}{|c|}
\hline Have license \\
\hline Have no license \\
\hline
\end{tabular}

\section{Physical Conditions}

Catering premises structures should allow protection against cross-contamination of food surfaces during operations. As indicated in Table 2, from 102 catering establishments service quarter 44(43\%), 43(42\%) and 15 (15\%) has good, fair and bad ventilation condition, respectively. No observed artificial ventilation in catering establishments of Agaro town at all. About 39(38.2\%), 48(47.1\%) and 15(14.7\%) service quarter of the establishments has good, fair and bad lightning, respectively. From 94 catering establishments who has kitchen $9(9.6 \%), 38(40.4 \%)$ and $47(50 \%)$ has good, fair and bad ventilation condition, respectively. About 8(8.5\%), 38(40.4\%) and $48(51.1 \%)$ kitchens of the establishments has good, fair and bad lightning, respectively, the fact that each room should ensure adequate lighting and air circulation. From 33 catering establishments who has storage room $8(24.2 \%), 11(33.3 \%)$ and $14(42.4 \%)$ has good, fair and bad ventilation condition, respectively. About $8(24.2 \%), 12(36.4 \%)$ and $13(39.4 \%)$ storage room of the establishments has good, fair and bad lightning, respectively. On the other hand, floor and walls surfaces of catering establishments must be maintained in a sound condition and be easy to clean and disinfect.

Table 2: Ventilation and lightning condition of catering establishments of Agaro town in March, 2013.

\begin{tabular}{|c|c|c|c|c|c|c|c|}
\hline \multirow{3}{*}{\multicolumn{2}{|c|}{ Variables }} & \multicolumn{6}{|c|}{ Status } \\
\hline & & \multicolumn{2}{|c|}{ Good } & \multicolumn{2}{|c|}{ Fair } & \multicolumn{2}{|c|}{ Poor } \\
\hline & & Frequency & $\%$ & Frequency & $\%$ & Frequency & $\%$ \\
\hline \multirow{2}{*}{ Service quarter } & Ventilation & 44 & 43 & 43 & 42 & 15 & 14.7 \\
\hline & Lightning & 39 & 38.2 & 48 & 47.1 & 15 & 14.7 \\
\hline \multirow{2}{*}{ Kitchen } & Ventilation & 9 & 9.6 & 38 & 40.4 & 47 & 50 \\
\hline & Lightning & 8 & 8.5 & 38 & 40.4 & 48 & 51.1 \\
\hline \multirow{2}{*}{ Storage room } & Ventilation & 8 & 24.2 & 11 & 33.3 & 14 & 42.4 \\
\hline & Lightning & 8 & 24.2 & 12 & 36.4 & 13 & 39.4 \\
\hline
\end{tabular}

Table 3: The sanitary construction of catering establishments premises of Agaro town in March, 2013.

\begin{tabular}{|c|c|c|c|c|c|}
\hline \multirow{3}{*}{ Parts } & \multirow{3}{*}{ Characteristics } & \multicolumn{4}{|c|}{ Response } \\
\hline & & \multicolumn{2}{|c|}{ Yes } & \multicolumn{2}{|c|}{ No } \\
\hline & & Frequency & $\%$ & Frequency & $\%$ \\
\hline \multirow{3}{*}{$\begin{array}{l}\text { Quarter } \\
\text { Service }\end{array}$} & Easily washable floor & 84 & 82.4 & 18 & 17.6 \\
\hline & Easily washable wall & 45 & 44.1 & 57 & 55.9 \\
\hline & Presence of ceiling & 96 & 94.1 & 6 & 5.9 \\
\hline \multirow{6}{*}{ Kitchen } & Presence & 94 & 92.2 & 8 & 7.8 \\
\hline & Easily washable floor & 13 & 13.8 & 81 & 86.2 \\
\hline & Easily washable wall & 6 & 6.4 & 88 & 93.6 \\
\hline & $\begin{array}{c}\text { Presence of } \\
\text { overcrowding }\end{array}$ & 51 & 54.3 & 43 & 45.7 \\
\hline & Presence of vectors & 87 & 92.5 & 7 & 7.4 \\
\hline & Presence of chimney & 75 & 79.8 & 19 & 20.2 \\
\hline \multirow{5}{*}{ Storage room } & Presence & 33 & 32.3 & 69 & 67.7 \\
\hline & Easily washable floor & 13 & 39.4 & 21 & 60.6 \\
\hline & Easily washable wall & 9 & 27.3 & 24 & 72.7 \\
\hline & $\begin{array}{l}\text { Presence of over } \\
\text { crowding }\end{array}$ & 23 & 69.7 & 10 & 30.3 \\
\hline & Presence of vectors & 27 & 81.8 & 6 & 18.2 \\
\hline
\end{tabular}

Majority $(82.4 \%)$ of the establishments service quarter has easily washable floor which is made up of concrete and the rest $18(17.6 \%)$ has no easily washable floor which are earthen and tile type. About $45(44.1 \%)$ of catering establishments service quarter has easily washable wall which is made up of brick and metal, and the rest 55(55.9\%) has no easily washable wall. Among 94 catering establishments kitchen, 13(13.8\%), 6(6.4\%) of them has easily washable floor and wall, respectively. Ceilings 
(or, where there are no ceilings, the interior surface of the roof) and overhead fixtures mustbe constructed and finished in a way that prevents dirt from building up and reduces condensation, the growth of undesirable mould and the shedding of particles. Ninety four percent of establishments service quarter have ceiling which are mainly made up of cloth and 5.9\% has no any ceiling (Data not shown). Even though the space of the kitchen must accommodate the food preparation processes, $54.3 \%$ of the kitchens have no adequate space (Data not shown).About $69 \%$ of the establishment has no separate storage room and $33(32.3 \%)$ has separate storage room for cooked food apart from raw food. Among establishments who has separate storage room, $13(39.4 \%)$ and $9(27.3 \%)$ has easily washable floor and wall, respectively. Vector control is not easy task in food establishments. It is very common to see flies in kitchens and food storage rooms. Cockroach and other flies are prevalent in $27(81.8 \%)$ of the establishments' storage room and in the rest $6(18.2 \%)$ it is not prevalent. Twenty three $(69.7 \%)$ of the storage room has no adequate space where as average area is four meter square (Table 3).

\section{Water Supply System}

A sustained source of safe water supply used for personal hygiene, food preparation and utensil cleaning is very necessary in catering establishments. Pertaining to source of water supply, all establishments get piped water as their main water source from the municipality. As shown in Figure1 the majority 72 (70.6\%) of catering establishments were accessible to compound tap followed by privately owned tap water17 (16.7\%) and public stand point $13(12.7 \%)$

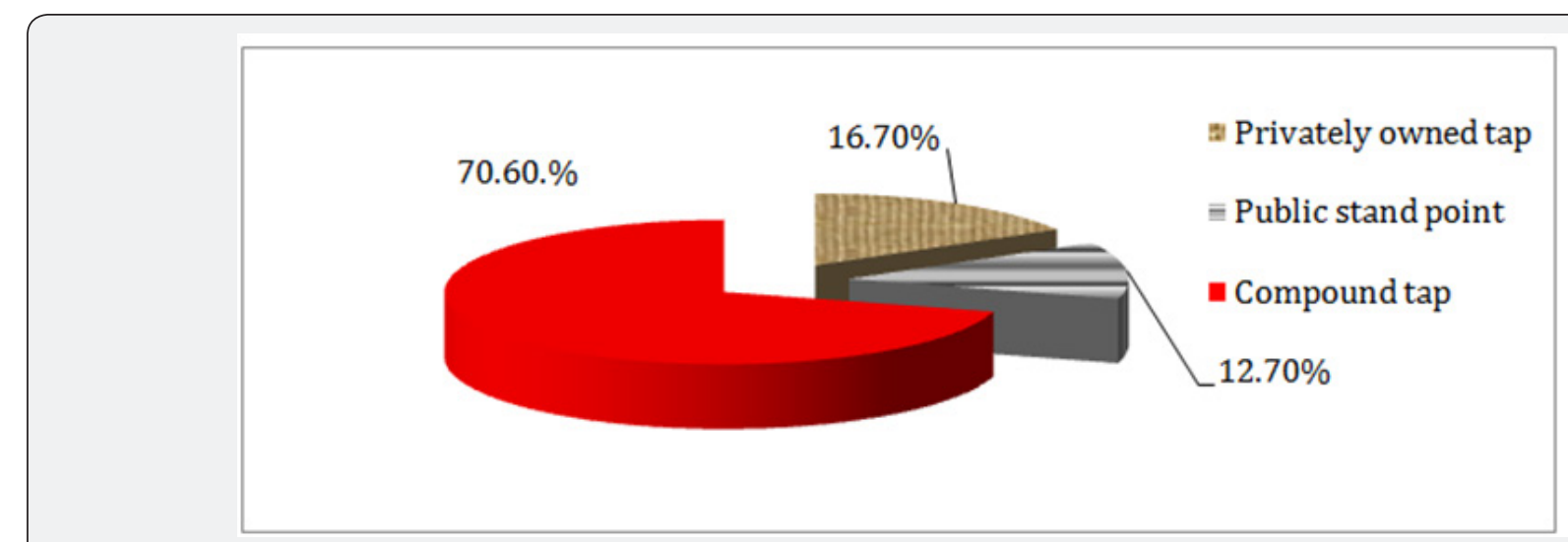

Figure 1: Water supply system of catering establishments of Agaro town in March, 2013.

\section{Distribution of Sanitary Facilities}

Wastes generated from catering establishments should be handled properly without polluting the immediate environment. Ninety nine $(97.1 \%)$ of the establishment has toilet facility and in the rest $3(2.9 \%)$ the facility is absent. The common type of excreta disposal system is found to be traditional pit latrine (TPL) with super structure 89(87.3\%) followed by TPL without super structure $7(6.9 \%)$ and ventilated improved pit latrine $3(2.9 \%)$.From 102 catering establishments, only 12(11.8\%) and $5(4.9 \%)$ were equipped with septic tank and soak away pit,respectively; while the rest85(83.3\%) dispose their liquid wastes indiscriminately (Table 4). Solid waste management of most $(88.2 \%)$ catering establishments was set out-set back residential collection system. And the rest $8(7.8 \%)$ and 4
(3.9\%) dispose their waste on open field at their backyard and in the pit, respectively (Table 4). Majority (83.3\%) of the catering establishments' have hand washing facilities where as the rest $16.7 \%$ has no hand washing facility. The number of establishments which have shower and not have shower was $41(40.2 \%)$ and 61 (69.8\%), respectively. From 102 establishments 45(44.1\%), 34(33.3\%) and 23(22.5\%) has three, two and one dish washing compartment. Sanitized equipment/ utensils drying racks were available only in $11(10.8 \%)$ of the establishment and in 91(89.2\%) it is not available. In 34(33.3\%) of the establishments there is proper storage for sanitized equipment and utensils, in the rest $68(66.7 \%)$ there is no proper storage (Table 4). Majority or 94 (92.2\%) establishments use detergents to sanitize food utensils. Whereas the rest $8(7.8 \%)$ use both detergents and hot water (data not shown).

Table 4: Liquid waste management, Solid waste management facilities and washing facilities Distribution of catering establishments of Agaro town, March, 2013.

\begin{tabular}{|l|c|c|c|}
\hline \multicolumn{2}{|c|}{ Liquid waste management facilities (a) } \\
\hline \multirow{2}{*}{ Characteristics } & \multicolumn{2}{c|}{ Number of establishments } \\
\cline { 2 - 4 } & TPL with super structure & Frequency & \% \\
\hline \multirow{3}{*}{ Latrine } & TPL without super structure & 79 & 6.9 \\
\cline { 2 - 4 } & VIPL & 3 & 2.9 \\
\cline { 2 - 4 } & Not available & 3 & 2.9 \\
\cline { 2 - 4 } & & 3 & \\
\hline
\end{tabular}


Juniper Online Journal of Public Health

\begin{tabular}{|c|c|c|c|}
\hline \multirow{3}{*}{$\begin{array}{l}\text { Liquid waste facility other than } \\
\text { latrine }\end{array}$} & Septic tank & 12 & 11.8 \\
\hline & Soak away pit & 5 & 4.9 \\
\hline & Indiscriminate disposal & 85 & 83.3 \\
\hline \multicolumn{4}{|c|}{ Solid waste management facilities (b) } \\
\hline \multirow{3}{*}{ Solid waste disposal method } & Pit & 4 & 3.9 \\
\hline & Open field burning & 8 & 7.8 \\
\hline & Collected by municipality & 90 & 88.2 \\
\hline \multirow{2}{*}{ Presence of waste receptacle } & Available & 5 & 4.9 \\
\hline & Not available & 97 & 95.1 \\
\hline \multicolumn{4}{|c|}{ Washing Facilities (c) } \\
\hline \multirow{2}{*}{ Hand washing facilities } & Yes & 85 & 83.3 \\
\hline & No & 17 & 16.7 \\
\hline \multirow{2}{*}{ Shower for staff } & Yes & 41 & 40.2 \\
\hline & No & 61 & 59.8 \\
\hline \multirow{2}{*}{ Three dish washing compartment } & Yes & 45 & 44.1 \\
\hline & No & 57 & 55.9 \\
\hline \multirow{2}{*}{$\begin{array}{c}\text { Presence of drying rack for } \\
\text { sanitized equipment and utensils }\end{array}$} & Yes & 11 & 10.8 \\
\hline & No & 91 & 89.2 \\
\hline \multirow{2}{*}{$\begin{array}{l}\text { Presence of proper storage for } \\
\text { sanitized equipment and utensils }\end{array}$} & Yes & 34 & 33.3 \\
\hline & No & 68 & 66.7 \\
\hline
\end{tabular}

There was statistically association $(\mathrm{p}<0.05)$ between pattern of inspection with availability of hand washing $\left(\mathrm{P}=0.00, \mathrm{x}^{\wedge} 2\right.$ $=37.8)$ and latrine facility $\left(\mathrm{P}=0.00, \mathrm{x}^{\wedge} 2=45.1\right)$ of catering establishments. This study result showed that only $60.8 \%$ of the establishments had sanitary inspection visits during the last six month which was found to be irregular. And there is statistically significant association $(\mathrm{p}<0.05)$ between pattern of inspection with the availability of latrine and hand washing facility in catering establishment. According to this study only $16.7 \%$ of the establishments have tap water inside the house which is not complying with the standard that states all ordinances demand that running water under pressure shall be easily accessible to all rooms in which food is prepared and served, and utensils and food containers are washed. The provision of proper and safe disposal of human waste excreta and sewage is the most important requirement for public food service establishment [3]. This study revealed that only $17.4 \%$ of the establishments were provided with proper and safe disposal of liquid waste disposal which is much lower when compared with the study done at Bahirdar town that shows $50 \%$ of the establishments have proper liquid disposal system [8]. This study shows that $92.1 \%$ of the establishments have proper solid waste disposal system which may be due the efforts of the municipality plus the local community. Though sanitary washing and handling of utensils is of greatest importance in the prevention of disease transmission, this study revealed that $44.1 \%$ of the establishments practice the standard sanitary (three comportment) washing technique. In a majority of the establishments, utensils were washed using one or two compartment only. This was probably due to food handlers and managers lack of knowledge about the consequences behind the constraints. The same problems were observed in a study done at Awassa [9]. The cleaning of soiled dishes and cup is an important way of preventing communicable diseases. In order, Even though the three bowls system can be encouraged to clean food utensils, two bowls is also acceptable because the hot water is used for rinsing and sanitizing. For sanitized utensils, drying racks were absent in (89.2\%) of the establishments which may result in contamination of food in the process of preparation, storing and serving. There was statistically no association ( $p>0.05$ ) between license status and availability of hand washing $\left(\mathrm{P}=0.10, \mathrm{x}^{\wedge} 2=2.71\right)$ and latrine facility $\left(P=0.09, x^{\wedge} 2=2.78\right)$ of catering establishments. There was statistically no association ( $p>0.05$ ) between license status and availability of hand washing and latrine facility $(P=0.09$, $x^{\wedge} 2=2.78$ ) which is in opposite of the study done at Bahirdar that states there was statistically significant association between hygienic setting and license status of the establishments [8]. Therefore, the likely cause for poor hygienic setting of catering establishments Agaro townis not due to lack of proper licensing system, rather it may be due to lack of regular inspection by the government bodies.The major water storage system were jerry cans $63(61.8 \%)$ which is followed by large barrel $31(30.4 \%)$ and tanker $8(7.8 \%)$ (data not shown). About $17(16.7 \%)$ of catering establishments didn't have any type of racks, shelves and cabinets for food and drink storage. Racks, shelves and cabinets were present in $82(80.4 \%), 63(61 \%)$ and $44(43.1 \%)$ proportion and not present in $20(19.6 \%), 39(38.2 \%)$ and $58(56.9 \%)$ proportion, respectively. Eighty nine (87.3\%) establishments has cold storage system and the rest $13(12.7 \%)$ has no cold storage system to store temperature dependent food and drink products (Figure 2). 


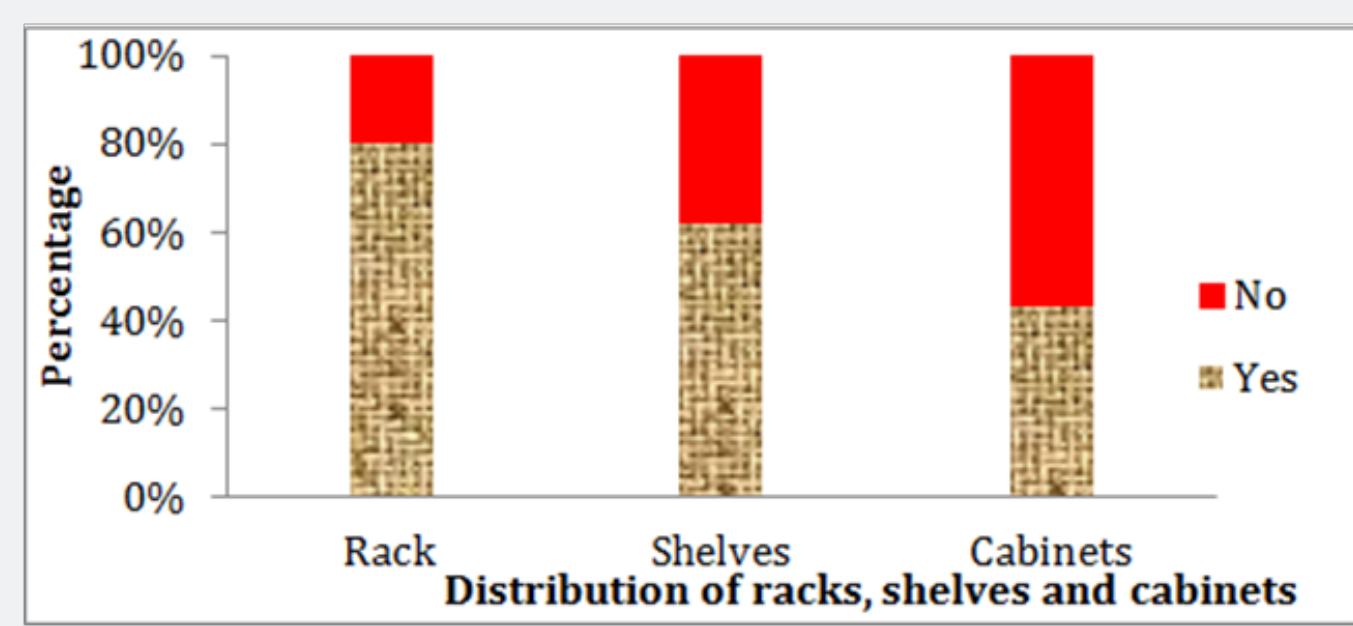

Figure 2: Distribution by presence of racks, shelves and cabinets of catering establishments of Agaro town, March 2013.

\section{Food Handlers Condition}

Literacy Status of Food handlers: From a total of 43 male and 59 female food handlers interviewed, only 18(17.6\%) were found to be illiterate whereas the rest 84(83.4\%) were found to be literate as indicated in Table 5. Among 102 food handler, only $37(35.3 \%)$ worn gown whereas $65(64.7 \%)$ do not worn gown. Only $26(25.5 \%)$ food handlers worn hair nets whereas $76(74.5 \%)$ do not worn hair nets. $68(67.6 \%)$ of food handler has trimmed and clean fingernails of hand whereas 34(32.4\%) of food handler has no trimmed and clean fingernails of hand. A sick food handler with symptoms of diarrhea, eye and ear discharges, skin infections, open cuts and wounds, or coughing should not continue working. They must be treated and be completely recovered before returning to work. Among the 102 food handler only 5(5.9\%) had health examination and it was done in irregularly.

Table 5: Literacy status food handlers of catering establishments in Agaro town, March 2013.

\begin{tabular}{|c|c|cc|}
\hline \multirow{2}{*}{ Educational status } & \multicolumn{2}{|c|}{ Food handlers } \\
\cline { 2 - 4 } & Frequency & 18.6 \\
\hline Illiterate & 19 & 41.2 \\
\hline Elementary(1-6) & 42 & 15.7 \\
\hline Junior elementary(7-8) & 16 & 21.6 \\
\hline Secondary(9-12) & 22 & 2.9 \\
\hline Higher education & 3 & 100 \\
\hline Total & 102 & & 2 \\
\hline
\end{tabular}

Table 6: Food handlers personal hygiene and related sanitary requirements status in catering establishments of Agaro town in March, 2013.

\begin{tabular}{|c|c|c|c|c|}
\hline \multirow{2}{*}{ Characteristics } & \multicolumn{3}{|c|}{ Response } \\
\cline { 2 - 5 } & \multicolumn{2}{|c|}{ Yes } & Frequency & No \\
\cline { 2 - 5 } & Frequency & \% & 65 & 64.7 \\
\hline Worn gown & 37 & 35.3 & 76 & 74.5 \\
\hline Worn hair nets & 26 & 25.5 & 99 & 97.1 \\
\hline Hands blistered & 3 & 2.9 & 97 & 32.4 \\
\hline $\begin{array}{c}\text { Fingernails trimmed and } \\
\text { clean }\end{array}$ & 68 & 67.6 & 100 & 94.1 \\
\hline $\begin{array}{c}\text { Have Medical checkup } \\
\text { Illness in the last one } \\
\text { month }\end{array}$ & 5 & 5.9 & 71 & 98.03 \\
\hline $\begin{array}{c}\text { Health education( } \\
\text { training) }\end{array}$ & 31 & 1.96 & & 6.6 \\
\hline
\end{tabular}




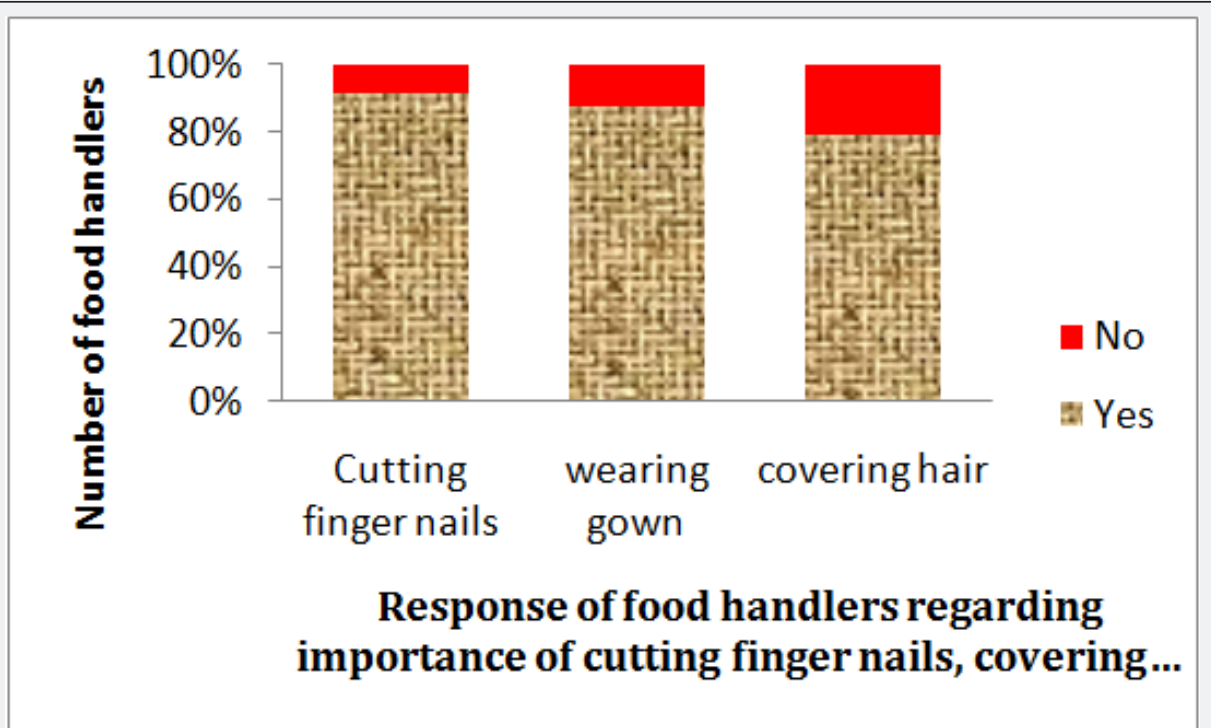

Figure 3: Response of food handler regarding cutting finger nails, covering hair and wearing gown at work site of catering establishments of Agaro town, March 2013.

The rest $97(94.1 \%)$ did not have any kind of medical checkups. Only $2(1.96 \%)$ of the food handler had illnesses in the last one month. Health education was given to $31(30.4 \%)$ of the establishments, the rest $71(69.6 \%)$ have not health education until the date of the survey (Table 6). Only 93(91.2\%), 89(87.3\%) and $81(79.4 \%)$ of food handlers believe that it is necessary to cut finger nails, to wear gown and to cover hair at work site, respectively. The rest $9(8.8 \%), 13(12.7 \%)$ and $21(20.6 \%)$ responded that it not is necessary to cut finger nails, to wear gown and to cover hair at work site, respectively (Figure 3). From 102 food handlers interviewed for the necessity of having medical checkup, 98(96.1\%) responded that it is necessary to have medical examination and the rest $4(3.9 \%)$ responded that it is not necessary to have medical examination (data not shown). More than $99 \%$ of food handlers believe that it is important to have training on proper food handling, food borne illnesses, and personnel hygiene and the rest responded that it is not necessary (data not shown). Almost all, 100(99\%) of food handlers were responded that it is important to wash hand before starting job, during interruption of job for tea break, after visiting toilet and the rest $1 \%$ responded that it is not necessary (data not shown).Generally from 102 food handlers interviewed, $73(71.5 \%)$ believe that medical examination, health education program, hand washing, cutting finger nail, covering hair and wearing gown at work site is important for the sake of their own health. There was statistically significant association $(p<0.05)$ regarding having training on proper food handling and personal hygiene, and gown wearing $\left(\mathrm{P}=0.00, \mathrm{x}^{2}=27.7\right)$ and finger trimming practice of food handlers $\left(\mathrm{P}=0.00, \mathrm{x}^{2}=11.2\right)$.

There was statistically no association ( $p>0.05)$ between the educational status and gown wearing practice of food handler $\left(P=0.475, x^{2}=3.52\right)$ and there was statistically significant association $(\mathrm{p}<0.05)$ between finger trimming practice and their educational status $\left(\mathrm{P}=0.00, \mathrm{x}^{2}=19.4\right)$. Food contamination cannot only happen as a result of the poor facilities, but it is also strongly associated with the personnel engaged in the food handling process until consumption. Regular medical checkup, wearing gown and hairnets, trimming finger nails were not collectively practiced by food handlers which is in parallel with the study done at Awassa [9]. There was statistically association ( $p<0.05$ ) between having training on proper food handling and personnel hygiene, and gown wearing and finger trimming practice of food handler. This study result is in agreement with the study done at Bahirdar town which states that there was significant difference between trained and non-trained food handlers [8]. The finger trimming practice of food handler also has a statistically association $(\mathrm{p}<0.05)$ with educational status of food handlers. And there was no association $(p>0.05)$ in between gown wearing practice and educational status of food handlers. Despite the fact that, good personnel hygiene and food handling practice are the basis for preventing the transmission of pathogens from food handlers to the consumer [15], this study revealed poor personal hygiene and food handling practice in majority of the establishments and there is lack of knowledge regarding to the importance of personnel hygiene which is in agreement with the study done at Bahirdar, Mekelle, Zeway and Awash-Sebat kilo town $[2,8,10,14]$.

\section{Conclusion}

In general this study revealed that there exist gross unhygienic settings that do not meet sanitary criteria of catering establishments related to liquid waste management, solid waste management system, water supply system, dish washing facilities and the physical condition of the establishments specially kitchens. The personnel hygiene of food handler in majority of the establishments can be stated as poor. The municipality should have to establish regular supervision and inspection system for catering establishment and give appropriate feedback to all owners and managers at regular interval. Persistent efforts 


\section{Juniper Online Journal of Public Health}

must be continued to encourage catering establishments to use the standard sanitary facilities by providing health information during the regular sanitary inspection visits. The existing regulatory body and municipality should create awareness through continued training of both food handlers and owners or managers.

\section{Acknowledgements}

The authors are grateful to the owners and food handlers of catering establishments in Agaro town, and Agarotown Municipality for their cooperation during the survey.

\section{Refernces}

1. WHO (1989) The role of food safety in health and report of joint FAO/ WHO Expert. Committee on food safety, Technical report series, WHO Geneva.

2. Kumie A, Genete K, Worku H, Kebede E, Ayele F, et al. (2002) The sanitary condition of public catering establishments in the district of Zeway. Ethio J Health deve 16(1): 95-104.

3. G Amanuel T (1987) Food hygiene principles and methods of food borne disease control with special reference to Ethiopia.

4. Jayant D Desphange, Deepak B Phalke (2013) Personal hygiene among food handlers in rular areas of northern Maharasata, India. p. 4-2.

5. Olson SL, MackinonL, Goulding J, Bean N, Slutsker (2000) Surveillance for food borne disease outbreaks-United States. Morb Mortal Wkly Rep 49(1): 1-62.

This work is licensed under Creative Commons Attribution 4.0 License DOI:10.19080/JOJPH.2018.03.555611
6. Central Statistical Agency (2007).

7. Daniel WW (1999) Biostatictics: A Foundation for Analysis in the Health Sciences. ( $7^{\text {th }}$ edn.); JohnWiley \& Sons, New York, USA.

8. Kibret M, Abera B (2012) Sanitary condition of Food Service Establishments and Food Safety Knowledge and practices of Food Handlers in Bahirdar town Amhara. Ethiop J Health Dev 22(1): 27-35.

9. T Mariam S, Roma B, Sorsa S, Worku S, Erose L (1999) Assessment of sanitary and hygiene status of catering establishments of Awasssa town. Ethiop J Health Dev 14(1): 81-98.

10. Zeru K, Kumie A (2007) Sanitary condition of food establishment in Mekelle town, Tigray, North Ethiopia. Ethiop J Health Dev 21: 3-11.

11. Addis Ababa Health Bureau (1994) Sanitary requirements for public food and drink establishments, and small scale food processing units. Amharic version 7: 11-17.

12. Hygiene and Environmental Health Department (1995) Sanitary guide line for food and drink establishments. Ministry of Health of Ethiopia, p. 15-16.

13. Fisseha G, Berhane Y, Teka GA (1999) Public catering establishments in Addis Ababa: physical and sanitary facilities. Ethiop J HlthDev 13(2): 127-134.

14. Kumie A, Mezene A, Amsalu A, Tizazu A, Bikila B (2006) The sanitary condition of food and drink establishments in Awash Sebat Kilo town, Afar region, Ethiopia. Ethio J Health deve 20(3): 201-203.

15. Evans HS, Madden P, Doudlas C, Adak GK, Obrien SJ (1998) General out breaks of infectios intestinal disease in England and Wales. Commun Dis Public Health 1: 165-171.

\section{Your next submission with Juniper Publishers} will reach you the below assets

- Quality Editorial service

- Swift Peer Review

- Reprints availability

- E-prints Service

- Manuscript Podcast for convenient understanding

- Global attainment for your research

- Manuscript accessibility in different formats

( Pdf, E-pub, Full Text, Audio)

- Unceasing customer service

Track the below URL for one-step submission https://juniperpublishers.com/online-submission.php 